\title{
The effect of delayed planting date on growth and cropping of strawberry plants
}

\author{
EWA ŻMUDA - DAWTIAN \\ Department of Pomology, Agricultural University, 58 Leszczyńskiego Street, 20-068 \\ Lublin Poland, e-mail: katsad@consus.ar.lublin.pl.
}

(Received: December 15, 1999)

\section{Sum mary}

To induce the late summer cropping (July - August ) of Elsanta strawberries, grown in one-year-production cycle, two experiments, based on a delayed planting term of ,frigo" plants were carried out. The plantings were started (established) in 1994 (site I, in Gorzyce) on May 14 (a), May 27 (b) and June 10 (c), and in 1996 (site II, Lublin) on June 5 (d), and June 18 (e). Site II was irrigated by dripping, while site I was not. In both sites, the early planting terms (a and d) have contributed to a better plant growth and cropping in comparison to the other treatment. Fruit yields amounted to 99, 75, 21, 452 and $290 \mathrm{~g} /$ plant for a, b, c, d and e, respectively. Two weeks' delay in planting term resulted in a deterioration of the fruit size, fruit mass and its chemical composition.

Key words: strawberry, delayed planting

\section{INTRODUCTION}

In the recent years there can be observed an increasing interest of consumers in the strawberry desert fruits in summer - autumn period, and so beyond the season of their traditional ripening in the field.

Production of strawberry of a late ripening variety as well as the repeatedly cropping ones creates a great chance to extend the supply of fresh fruits on the market, although it is not popular enough due to the small and irregular yielding. Moreover, the fruits are smaller than those of the varieties which crop in a traditional time (Chercuitte et al., 1991). A controlled cultivation of strawberries in the field is an expensive technology because of the necessity to use the best quality plant material of ,frigo" type, the selection of the big fruit varieties, irrigation of the plantation and mulching the soil in order to protect the fruits from getting sandy. It offers, however, an opportunity to prolong the strawberry supply from field plantations, without using any covering. 
The objective of this study was to investigate an application of controlled latesummer strawberry production using ,frigo" plants in the Lublin and Tarnobrzeg region.

\section{MATERIALS AND METHODS}

The investigation was carried out in two yearly cycles in 1994 (experiment A) in a private farm in Gorzyce (Tarnobrzeg region), and in 1996 (experiment B) in the experimental orchard of Agricultural University in Lublin.

\section{Experiment A}

The „f frigo" plants of Elsanta strawberries were planted in intervals on May 14, May 27, and June 10. The plants were planted in clay sandy soil in spacing $20 \times 80 \mathrm{~cm}$ using 100 plants per plot replicated five times. The plants were watered immediately after planting.

Before the investigation started, a mineral fertilization of $54 \mathrm{~kg} \mathrm{~N}, 25 \mathrm{~kg} \mathrm{P}_{2} \mathrm{O}_{5}$ and $76 \mathrm{~kg} \mathrm{~K} \mathrm{~K}_{2} \mathrm{O} / \mathrm{ha}$ was applied. The manure at the rate of $40 \mathrm{t} / \mathrm{ha}$ ( for forecrop) was used.

Till flowering, the plots were weeded out mechanically and, then, the planting was mulched with straw.

During the experiment plants were treated according to a routine spray program.

Plant growth pattern was determined using the number of leaves, inflorescences and a respective number of flowers, from 20 plants/plot. The weight of yield was recorded from each plot. The qualitative analysis (fruit dry mass and soluble solids) was done on fruit collected at the main harvest. In $1994 \mathrm{r}$. the air temperature in May and June was close to the average values of many years periods. July was a very warm month. The average temperature was $21.4^{\circ} \mathrm{C}$, in comparison to the average value of the years $1965-1994\left(17.9^{\circ} \mathrm{C}\right)$, and August and September were somewhat warmer than the average values in many years periods. The rainfalls in May were high, and in June they were low. July was a very dry month (the rainfall of $13.1 \mathrm{~mm}$, and the average value for many years period $-70.6 \mathrm{~mm}$ ), than the rainfalls were more abundant than usually during many years period.

\section{Experiment B}

Leafy ,, frigo” plants of cv. Elsanta strawberry with a crown of diameter ca. 14 $15 \mathrm{~mm}$ were planted at $30 \times 90 \mathrm{~cm}$, on each of two occasions, i.e. on June 5 and June 18 .

Fifty plants per plot in nine replications was used. This experiment was established on the fallow soil composed of medium clay.

The plants were irrigated with drip irrigation, which frequency depended upon local weather conditions.

In June, about $45 \mathrm{~mm}$ of rainfall was applied, and in the remaining months, the watering took place after every fruit harvest.

Soil test that was performed before planting establishment indicated no need for $\mathrm{P}, \mathrm{K}$ and $\mathrm{Mg}$ fertilization due to high availability of these elements in the soil. The plants were nitrogen fertilised only at 50 and $30 \mathrm{~kg} \mathrm{~N} / \mathrm{ha}$ on two occasions, the first after plant establishment in the soil, and the second before blossoming, respectively.

Till flowering, the plots were weeded out mechanically and, then, the planting was mulched with straw. 
During the experiment plants were treated according to a routine spray program.

Plant growth pattern was determined using the number of leaves, shoots, inflorescences and a respective number of flowers, from 20 plants/plot. The weight of yield and fruit size distribution ( after specifications of OECD applicable in international trade in the EU) were recorded from each plot. The qualitative analysis (mass of 100 fruits, contents of the extract, dry mass, anthocyanins, monosaccharides, organic acids and vitamin C) was done on fruit collected at the main harvest. In 1996, in the period when the investigation was carried out (June - September) the air temperature was pretty favourable for the growth and yield of strawberry, it was close to the average value of many years $\left(16.5,16.4\right.$ and $17.7^{\circ} \mathrm{C}$ in the month VI, VII and VIII ) with exception of the cold month of September $\left(9.6^{\circ} \mathrm{C}\right.$ in comparison to many years temperature $12.9^{\circ} \mathrm{C}$ ). The period of rainfall scarcity occurred in June (during the intensive plant growth period), while in August and September the rainfall was more abundant than in the period of $1951-1990$.

In both experiments the results were elaborated statistically by the method of variance analysis, and the meaning of the found differences was estimated with the help of T Tukey's test at a level of $5 \%$.

\section{RESULTS}

\section{Vegetative growth}

Strawberry plants planted most early, i. e. on May 14, 1994, produced the biggest amount of leaves, inflorescence and flowers (Table 1). The delay of the term had essentially weakened their growth determined according to the above mentioned features. Similar relationships were found in experiment B (Table 2), where the plants planted in the first term (June 5) were in fact more increased, their foliage was much more abundant and they had more inflorescence in comparison to the plants planted with about two weeks' delay- June 18 .

Table 1

Influence of the planting term of ,frigo" plants on growth, cropping and quality of Elsanta strawberry fruits (Gorzyce, 1994).

\begin{tabular}{|l|c|c|c|}
\hline \multirow{2}{*}{ Characteristics } & \multicolumn{3}{|c|}{ Planting date } \\
\cline { 2 - 4 } & May 14 & May 27 & June 10 \\
\hline Number of leaves per plant & $22.8 \mathrm{c}$ & $18.3 \mathrm{~b}$ & $15.6 \mathrm{a}$ \\
Number of inflorescences per plant & $2.3 \mathrm{c}$ & $1.9 \mathrm{~b}$ & $1.6 \mathrm{a}$ \\
Number of flowers per plant & $22.0 \mathrm{c}$ & $19.3 \mathrm{~b}$ & $15.8 \mathrm{a}$ \\
Flowering onset & June 14 & June 26 & July 6 \\
Harvest term & July $7-14$ & July $20-$ August 8 & August $1-12$ \\
Total yield per plant $(\mathrm{g})$ & $99.9 \mathrm{c}$ & $76.0 \mathrm{~b}$ & $22.4 \mathrm{a}$ \\
Commercial yield per plant $(\mathrm{g})$ & $99.9 \mathrm{c}$ & $74.5 \mathrm{~b}$ & $21.3 \mathrm{a}$ \\
Total yield $\left(\mathrm{kg} / 100 \mathrm{~m}^{2}\right)$ & $62.43 \mathrm{c}$ & $47.51 \mathrm{~b}$ & $14.01 \mathrm{a}$ \\
Commercial yield $\left(\mathrm{kg} / 100 \mathrm{~m}^{2}\right)$ & $62.43 \mathrm{c}$ & $46.56 \mathrm{~b}$ & $13.31 \mathrm{a}$ \\
Fruit dry mass $(\%)$ & $13.04 \mathrm{a}$ & $15.68 \mathrm{~b}$ & - \\
Soluble solids $(\%)$ & $11.75 \mathrm{a}$ & $11.45 \mathrm{a}$ & - \\
\hline
\end{tabular}

The average values in the Table, followed by the same letters, do not significantly differ. 
Table 2

Influence of the planting term of ,frigo" plants on growth and cropping of Elsanta strawberries (Lublin, 1996).

\begin{tabular}{|c|c|c|}
\hline \multirow{2}{*}{ Characteristics } & \multicolumn{2}{|c|}{ Planting date } \\
\hline & June 5 & June 18 \\
\hline Number of leaves per plant & $12.9 \mathrm{~b}$ & $8.9 \mathrm{a}$ \\
\hline Number of crowns per plant & $2.9 \mathrm{~b}$ & $2.5 \mathrm{a}$ \\
\hline Number of inflorescences per plant & $5.5 \mathrm{~b}$ & $4.4 \mathrm{a}$ \\
\hline Number of flowers per plant & $58.1 \mathrm{~b}$ & $36.4 \mathrm{a}$ \\
\hline Flowering onset & June 28 & July 13 \\
\hline Harvest date & July 26 - September 9 & August 7 -Steptember 9 \\
\hline Semi-harvest date & August 5 & August 19 \\
\hline Total yield per plant $(\mathrm{g})$ & $452 \mathrm{~b}$ & $290 \mathrm{a}$ \\
\hline Commercial yield per plant $(\mathrm{g})$ & $425 \mathrm{~b}$ & $265 \mathrm{a}$ \\
\hline Total yield $\left(\mathrm{kg} / 100 \mathrm{~m}^{2}\right)$ & $167.38 \mathrm{~b}$ & $107.39 \mathrm{a}$ \\
\hline Commercial yield $\left(\mathrm{kg} / 100 \mathrm{~m}^{2}\right)$ & $157.50 \mathrm{~b}$ & 98.26 a \\
\hline
\end{tabular}

\section{Time of flowering and ripening}

In experiment $\mathrm{A}$ the onset of flowering of the plants planted most early (May 14) took place after 32 days since they had been planted. In the next planting term ( May 27 , June 10 ) plant flowering was accelerated and it started after 30 and 25 days respectively. The length of the period which had gone by since the planting of the plants until the beginning of the fruit harvest was 55 and 52 days respectively for the plants planted on May and June. The delay of the term as well as the drought and the heat shortened the period of harvesting from 22 to 19 and 13 days, respectively, and the number of the collection (harvests) from 11 to 10 and 7. Generally, the harvesting had lasted since July 7 until August 12 (Fig. 1)

In experiment $B$ in both terms of planting of the plants (June 5 and 18) the number of the days passing since the moment of planting until the beginning of strawberry flowering was approximate and it was respectively 23 and 25 days. After the next 28 and 25 days respectively for both terms of planting, the plants began to fructify. Collecting of the fruits of the first term started in the end of July, after about seven weeks from the moment of their planting, and they lasted 6.5 weeks, i.e. until September 9 . Nineteen croppings were collected in that period. The strawberry plants planted in the second term had also fructified after seven weeks, but their cropping lasted a shorter period (about 5 weeks) until September 9, and they occurred fourteen times (Fig. 2).

\section{Cropping}

The results concerning the quantity of strawberry fruit cropping and its structure are placed in Table 1 and 2 . In experiment $\mathrm{A}$, the fruit yielding of the delayed cultivation were average of about $65 \mathrm{~g} /$ plant $\left(40,76 \mathrm{~kg} / 100 \mathrm{~m}^{2}\right)$. The best yielding was received from the plants planted in the earliest term (EP). As the planting term delayed an essential decrease in the fruit yielding took place. The contribution of the commercial yielding in the general one was $95 \%$ to $100 \%$ (an average ratio). In experiment B, the strawberry yielding of the first planting term was higher by $36 \%$ in comparison to the one collected 
from the plants planted 2 weeks later. Counting of one single plant, the yield was 0.45 $\mathrm{kg}\left(167,38 \mathrm{~kg} / 100 \mathrm{~m}^{2}\right)$, and in case of the second planting term: $0.29 \mathrm{~kg}(107,39 \mathrm{~kg} /$ $100 \mathrm{~m}^{2}$ ). The fruits collected from the EP plants were better quality than that from plants planted later (LP). LP plants produced significantly less fruits of class extra than EP plants. EP plants produced only $15 \%$ of fruits of the 1 st and 2 nd choice while the LP plants up to $25 \%$.

\section{Mass of $\mathbf{1 0 0}$ fruits}

The size of the commercial fruits was significantly differentiated (Table 3 , the data received in experiment $\mathrm{B}$, Lublin). In the first planting term, larger fruits were obtained than those collected from the plants planted in later term. Similar differences in mass of 100 fruits could be observed within the given choices: extra, as well as the I and II.

Table 3

Influence of the planting term of ,frigo" plants on the quality of Elsanta strawberries (1996).

\begin{tabular}{|c|c|c|}
\hline \multirow{2}{*}{ Characteristics } & \multicolumn{2}{|c|}{ Planting date } \\
\hline & June 5 & June 18 \\
\hline Mass of 100 fruits (commercial yield) & $1066.7 \mathrm{~b}$ & $898.5 \mathrm{a}$ \\
\hline Mass of 100 fruits (Extra size yield) & $1295.0 \mathrm{~b}$ & $1163.0 \mathrm{a}$ \\
\hline Mass of 100 fruits (size I + II, yield) & $601.5 \mathrm{a}$ & $567.0 \mathrm{a}$ \\
\hline \multicolumn{3}{|l|}{$\begin{array}{l}\text { Fruit size distribution, total yield (\%) } \\
\text { Class (size, in mm) }\end{array}$} \\
\hline Extra $>25 \mathrm{~mm}$ & 78. b & $65.7 \mathrm{a}$ \\
\hline I and II, $22-25 \mathrm{~mm}$ & $15.4 \mathrm{a}$ & $25.8 \mathrm{~b}$ \\
\hline $\begin{array}{l}\text { Outside of choice } \\
\text { (Not saleable) }\end{array}$ & $5.9 \mathrm{a}$ & $8.5 \mathrm{~b}$ \\
\hline \multicolumn{3}{|l|}{ - Commercial } \\
\hline Extra & $83.6 \mathrm{~b}$ & $71.8 \mathrm{a}$ \\
\hline I and II & $16.4 \mathrm{a}$ & $28.2 \mathrm{~b}$ \\
\hline \multicolumn{3}{|l|}{ Contents of $\ldots$ in fruit $(\%)$} \\
\hline Dry mass & $12.13 \mathrm{~b}$ & $9.39 \mathrm{a}$ \\
\hline Soluble solids & $9.0 \mathrm{~b}$ & $6.5 \mathrm{a}$ \\
\hline Vitamin $\mathrm{Cmg} \%$ & $49.65 \mathrm{~b}$ & $44.68 \mathrm{a}$ \\
\hline Organic acids & $0.68 \mathrm{a}$ & $0.86 \mathrm{~b}$ \\
\hline Monosaccharides & $8.03 \mathrm{~b}$ & $4.66 \mathrm{a}$ \\
\hline Anthocyanins & $0.0098 \mathrm{a}$ & $0.0090 \mathrm{a}$ \\
\hline
\end{tabular}




\section{Fruit quality}

In experiment $\mathrm{A}$, no essential influence of delayed planting term on the contents of extract in fruits was observed except an increase in the contents of dry mass in strawberries of the second planting term, i. e. on May 27 (Table 1).

In experiment B, there was a distinct influence of the planting term for "frigo" variety on the chemical composition of the fruits (Table 3 ).

The fruits from EP plants contained more extracts, sugars and vitamin $\mathrm{C}$ in comparison to the fruits from LP plants. Moreover, they contained twice as much proportion of sugars to acids, more of dry mass, and they were more intensively coloured due to the higher contents of anthocyanins.

Fig 1. Harvest pattern of Elsanta strawberry (Gorzyce, 1994) dependent on planting dates

a) I planting date (14.V.)

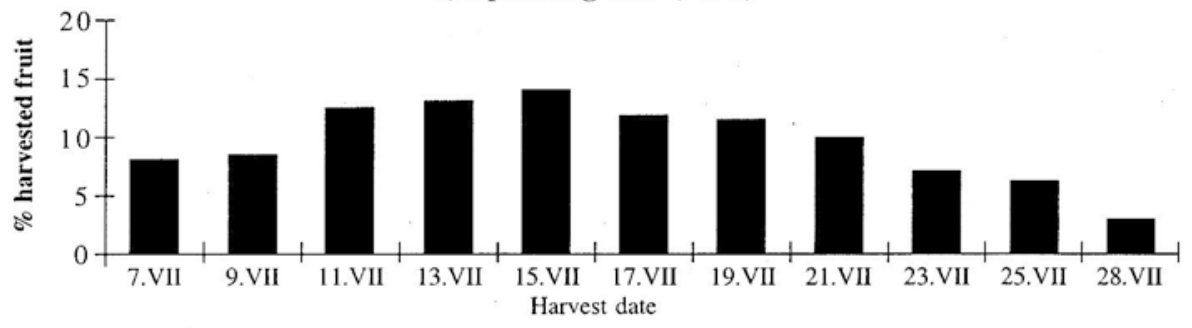

b) II planting date (27.V.)

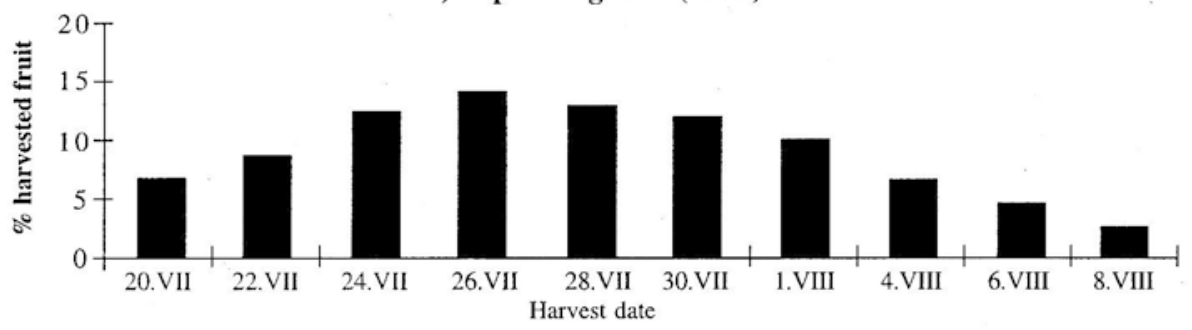

c) III planting date (10.VI.)

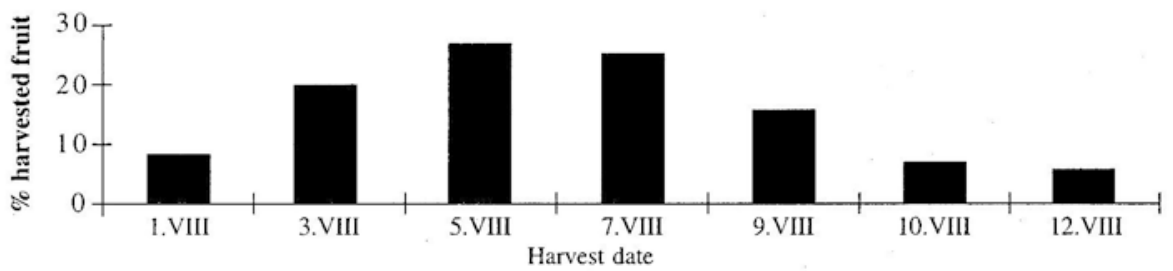


Fig 2. Harvest pattern of Elsanta strawberry (Lublin, 1996) dependent on planting dates

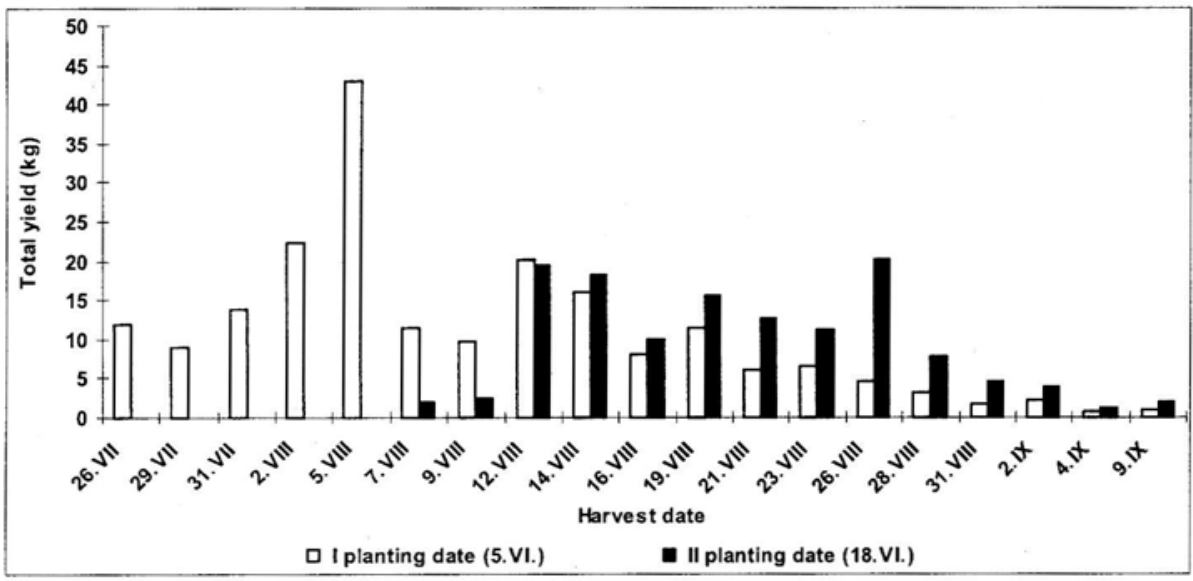

\section{DISCUSSION}

The obtained results confirmed the importance of planting terms of ,frigo" plants for their growth, cropping and fruit quality of Elsanta cultivar. The plants started to bear fruit $7-7.5$ weeks after planting. It agrees with the observation by Dijkstra (1989), who reports that in the field production the planting term should be settled depending on the expected cropping term which takes place after 7 to 8 weeks since their planting.

It is generally admitted (Żurawicz, 1993, Jagieliński, 1994, Kowalska, 1994, Szczygieł and Pierzga, 1995) that the strawberries of ,frigo" type, planted in the turning point of spring and summer and being in the state of a full hibernation, break into flower after 30 days since the beginning of vegetation, and after the following 30 days they enter into the phase of fruit ripening. In the experiments presented here the period of time since the beginning of blossoming ranged from 23 - 32 days, while the period from the beginning of the fruit cropping was essentially shorter: 23 to 28 days. A rapid growth of plant in the conditions of an non-irrigated strawberry plantation in Gorzyce (experiment A) had most probably taken place due to a high air temperature in July, and insufficient rainfall (total rainfall in June and July, was hardly $48 \mathrm{~mm}$ at the demand of $220-245 \mathrm{~mm}$ (Rebandel, 1988). It was probably due to low productivity of the plants (about 21 to $100 \mathrm{~g}$ of fruits per plant, i.e. $13-62 \mathrm{~kg} / 100 \mathrm{~m}^{2}$ ). An acceleration of the strawberry plant growth and their good cropping level in Lublin (experiment B) might have been related to the fact that the ,frigo" plants were abundant in leaves and strongly rooted, and thanks to it they started to grow rapidly after planting, giving a large amount of inflorescences up to 5.5 for plant that equaled to 58,1 flowers/ plant. The period of their adaptation to the environment occurred in favourable conditions of a warm and dry weather, and a simultaneous irrigation and mulching with straw. Scheerens and Brenneman (1994) mention the positive influence of similar conditions on strawberry cropping. Chercuitte et al. (1991) report that the soil type 
is an important factor in strawberry cultivation, whereas the poor clayey sand with a limited water availability does not contribute to strawberry abundant cropping what can be reflected by the results of the investigation carried out in Gorzyce (in 1994; experiment A). Favourable soil conditions in experiment B could have possibly resulted in good cropping of the plants. From literature (Radajewska et al., 1994, Anonymous, 1996) it results that the plants of type A+, of an average diameter of the crown over $16 \mathrm{~mm}$ should develop at least 2 inflorescences each, and the plants of many crowns (multicoronal) develop at least several of them. In this investigation (Gorzyce) the smaller plants with a crown diameter of 14 to $15 \mathrm{~mm}$, developed more than 2 inflorescences, however, as the delayed period prolonged, they evidently developed a smaller number of them. The EP plants, developed many more inflorescences (5.5 pieces/plant) than one reports in literature. The LP plants developed a smaller number of inflorescences (4.4 pieces/plant) than those planted earlier. Dominikowski (1994) reports that a leafless plantlets of Elsanta variety in selection A+ gives usually 22.2 flowers. In the experiment B the plant materials were in selection class A. They were with leaves and very abundantly rooted. Perhaps, that was why they had much more flowers (58.1 and 36.9 ) in consecutive planting terms. Basing on the observation made by many authors (Chercuitte et al., 1991, Dominikowski, 1994, Żurawicz, 1994) it results that the strawberry plants, of a crown diameter over $15 \mathrm{~mm}$, should yield 150 to $270 \mathrm{~g}$ of fruits. Terrettaz and Carron (1992) received, from the Elsanta variety in selection , frigo standard", planted on June 1, a yield of about 740 $\mathrm{g}$ of fruits from a plant. In these two experiments, an average yield/plant was $74.5 \mathrm{~g}$ $\left(46,5 \mathrm{~kg} / 100 \mathrm{~m}^{2}\right)$ and $452.0 \mathrm{~g}\left(167,3 \mathrm{~kg} / 100 \mathrm{~m}^{2}\right)$ for similar planting terms: May 27 (Gorzyce) and June 5 (Lublin), respectively.

As the planting term delayed, a decrease in the amount of the cropping was observed. This is with agreement with observations of Schmitz and Lenz (1989), and Kowalska (1994). A two weeks delay in planting the ,frigo" plants resulted in a considerable reduced growth of the plants, bringing about a decrease in cropping by 26 to $36 \%$.

A delay in the planting term has evidently deteriorated the strawberry quality, resulting in a decrease of average fruit mass. It also reduced the extra choice in saleable crop, simultaneausly increasing the amount of non-commercial fruits. It could have been a result of a less favourable meteorological conditions, especially a considerable rainfall during the cropping season (Lublin). Before one started the collection of the fruits from the plants, planted in the later term (experiment B), one had already managed to collect half of the strawberry cropping in the plots, initiated earlier. Counting on the mass, it was an equivalent of $75 \%$ of total cropping of the plants, planted in the later term.

Applying various planting terms resulted in changes in the chemical composition of the fruits of Elsanta cultivar. The strawberries collected from the LP plants were weakly coloured (small contents of anthocyanins). They contained more of organic acids and definitely less of vitamin C, extract, dry mass and sugars than those from the EP plants. About the modification of the physico-chemical composition of strawberry fruits, depending on the variety and the conditions of cultivation, report Mannini and Gallina (1994) as well as Woźniak and Walerowski (1994). 


\section{CONCLUSIONS}

Basing on the results received in two experiments of one year's duration, the following conclusions were formed:

1. The strawberries in the non-irrigated areas (Gorzyce, 1994) cropped in July and beginning of August, giving low cropping from a plant, equal to 21 to $100 \mathrm{~g} \mathrm{(1,3} \mathrm{-} \mathrm{6,2} \mathrm{t/ha)} \mathrm{and} \mathrm{decreasing} \mathrm{as} \mathrm{the} \mathrm{planting} \mathrm{term} \mathrm{delayed.}$

2. In case of the irrigated field plantation (Lublin) the cropping of cv. Elsanta, which was planted in the I or in the II decade of June, had taken place in late summer and amounted to 0.45 and $0.29 \mathrm{~kg} / \mathrm{plant}$, i.e. 16.6 and $10.7 \mathrm{t} / \mathrm{ha}$, respectively.

3. The ,frigo" plants, planted in the earlier term (May 14, May 27, experiment A; June 5, - experiment B) were more leafy, developed more shoots, and had more flowers in comparison to those planted later, ie. on June 10 and June 18.

4. Regardless of establishment time of plantation, strawberry cropping started after about 7 to 7.5 weeks from the time of planting.

5. A delay in the planting term shortened the strawberry cropping period.

6. The plants, which were planted earlier, yielded better than those planted two weeks later.

7. A decrease in fruit quality was observed as the term of starting the plantation delayed; the fruits from the plants planted on June 18 were smaller and contained less vitamin C, dry mass, extract, anthocyanins and sugars. They contained more organic acids than fruits from the plants planted on June 5 (experiment B).

8. The irrigation seems to be indispensable in the delayed strawberry field cultivation.

\section{REFERENCES}

A n o nymous, 1996: Rodzaje sadzonek „frigo” truskawek. Hasło Ogrodnicze, 2: 11-12.

Chercuitte L., Sullivan J. A., Desjardins Y. D., Bedard R., 1991: Yield Potential and Vegetative Growth of Summer-planted Strawberry. J. Amer. Soc. Hort. Sci., 116, 6: $930-936$.

Dijkstra J., 1989: The use of cold stored waiting-bed plants for a late harvest. Acta Horticulturae, 265: $207-214$.

Dominikowski J., 1994: Zasady produkcji i przechowywania sadzonek truskawek typu „frigo". Szkółkarstwo, Nr specjalny: $13-14$.

J a g i e li ńs k i J., 1994: Sterowana produkcja truskawek w gruncie. Sad Nowoczesny, 1: $19-20$.

Kowalska J., 1994: Truskawki od wiosny do jesieni. Owoce Warzywa Kwiaty, 12: 6 - 7.

Mannini P., Ga1lina D., 1994: Risposta produttiva e qualitativa della fragola all'irrigazione.. Rivista di Frutticoltura e di Ortofloricoltura, 56, 4: 69 - 73.

Radajewska B., A umiller A., Wolniak S., 1994: Produkcja sadzonek typu "frigo" do uprawy sterowanej truskawki. Wpływ terminu szkółkowania na jakość sadzonek. Sterowana uprawa truskawki. SITO, Poznań, 43 - 45.

Rebandel Z., 1988: Truskawki i poziomki. PWRiL Warszawa.

Scheerens J. C., Brenneman G. L., 1994: Effects of cultural systems on the horticultural performance and fruit quality of strawberries. Research Circular, Ohio Agricultural Research and Development Center, Wooster, 298: 81 - 98.

Schmitz F., Lenz F., 1989: Die Bedeutung des Pflanzzeitpunktes fur Wachstum und Ertrag bei den Erdbeersorten Elvira, Tenira, Korona und Bogota. Erwerbstobstbau, 31, 5: 118 - 122. 
Szczygiel A., Pierzga K., 1995: Truskawka. Hortpress Sp. Z o.o., Warszawa, ss. 54.

Terrettaz R., Carron R., 1992: Essai de dates de plantation et de types de plants du fraisier Elsanta en montagne. Revue suisse Vitic. Arboric. Hortic., 24, 6: $367-369$.

Woźniak W., Walerowski M., 1994: Charakterystyka fizyko - chemiczna owoców siedmiu odmian truskawki z uprawy przyspieszonej. Sterowana uprawa truskawki. SITO, Poznań: $15-19$.

Żurawicz E., 1993: Nowoczesne technologie produkcji deserowych owoców truskawki. Ogólnopolska Konferencja Truskawkowa. ISiK Skierniewice, 8 czerwca 1993: 7 - 10.

Żurawicz E., 1994: Nowe możliwości produkcji deserowych owoców truskawek. Hasło Ogrodnicze, 10: $11-12$.

\section{Wpływ opóźnionego terminu sadzenia na wzrost i owocowanie roślin truskawki}

\section{Streszczenie}

Dwa jednoroczne cykle badań z opóźnionym terminem sadzenia roślin „frigo” odm. Elsanta prowadzono w 1994 r.: 14 V, 27 V i 10 VI (Gorzyce) i w 1996 r.: 5 VI i 18 VI (Lublin) w celu uzyskania późnoletniego zbioru owoców (lipiec - wrzesień). Silniejszy wzrost roślin i wyższe plony uzyskano w. obu doświadczeniach przy wcześniejszych terminach sadzenia. Plonowanie w przeliczeniu na roślinę wynosiło odpowiednio: 99, 75 i 21 g oraz 452 i 290 g owoców, przy czym w Lublinie zastosowano nawadnianie kroplowe. Dwutygodniowe opóźnianie terminów sadzenia roślin spowodowało pogorszenie struktury plonu handlowego oraz jakości owoców, tj. masy 100 owoców i ich składu chemicznego. 